\title{
7 | Myriad stories: constructing expertise and citizenship in discussions of the new genetics
}

\author{
RICHARD TUTTON, ANNE KERR AND \\ SARAH CUNNINGHAM-BURLEY
}

\section{Introduction}

In this chapter, we explore the ways in which people in the UK discussed the patenting of genes in a series of focus group conversations. We consider in particular people's discussion of the case of Myriad Genetics, a US company that holds patents on BRCA1 and BRCA2, two genes involved in the hereditary forms of breast and ovarian cancer. The Myriad case was a vignette in our study of the ways in which people position themselves and others when talking about access to genetic information, particularly the issues of ownership and regulation. ${ }^{1}$ We introduced this case to the focus groups to engender discussion about the implications of patenting for genetic testing. We are interested in the ways in which people took on the roles of 'expert' or 'citizen', explicitly or implicitly, when they considered these issues, and what types of knowledge-claims and moral judgements these positions involved. The discussions about Myriad covered concerns about competition within science and medicine, the accuracy of different types of genetic tests, the globalization of genetic information and the relationships between multinational firms, national governments, scientific and health professionals, public healthcare, patients and consumers. These wider issues of commercialization and the public/private interface surfaced at different points in the focus group discussions, and responses to these embraced moral, political and economic arguments. What people bring to these debates, and the extent to which they are heard or can influence policy, depends on constructions of expertise and citizenship and the different knowledges, experiences and subjectivities implicated in such roles.

After providing some background to the Myriad case we discuss the focus group methodology that we employed, before moving on to analyse the different ways in which groups discussed Myriad. The analysis provides an outline of the different ways in which groups, and sometimes individuals, came to different or similar positions; reflection about the ways in which knowledge-claims and moral values were involved; and discusses the reasons why particular groups or individuals may have framed their accounts in these ways. We identified two main ways in which Myriad 
was constructed in these discussions: as an exemplar and as a pariah - although these should be seen as two sides of the same coin as both interrogate the relationship between Myriad's actions and the role of private enterprise in the realm of genetic research, testing and healthcare. These versions of Myriad are highly flexible and contingent, and can be understood only within the context of these research conversations. Our analysis emphasizes such contingency by examining the construction of expertise and citizenship, and offers an interpretation of why particular groups may settle upon specific subject positions vis-à-vis gene patenting and Myriad's activities. We deliberately do not attempt to reach a conclusion about what the majority of groups thought ought to happen with respect to the enforcement of the Myriad patent in the UK, or about the regulation of gene patenting more generally. Indeed, we explicitly reject such an analytical construct because it would be too simplistic, given that people's accounts of these issues are neither static nor resolute. We also avoid categorizing groups according to types such as 'layperson' or 'professional', and comparing their views within this framework, as this involves fixed notions of expertise and laity that do not do justice to the range of authority claims involved in the discussions.

We end the chapter by reflecting upon the implications of our analysis for exercises in public consultation and professional-public dialogue about genetics. We argue that normative theories of expertise (see Collins and Evans 2002) or ideal models of citizen participation, such as citizens' juries, involve setting up artificial boundaries between citizenship and expertise, and between the knowledge-claims and moral values on which they are based - boundaries that are forever changing in discursive practice. Analysts and participants alike need to pay more attention to the structure and function of 'authority claims' in these types of public-professional dialogue, in order to answer the questions as to why they are being made, by whom, in what context and to what effect.

\section{A Myriad story}

The US-based company, Myriad Genetics, holds international patents on BRCA1 and BRCA2, two genes involved in hereditary forms of breast and ovarian cancer (Dalpé et al. 2003). There has been marked opposition to these patents in several European countries and Canadian provinces on the grounds that they are too broad, with the effect of placing Myriad in a monopolistic position in relation to BRCA testing (Clement 2002; European Parliament 2001; Henley 2001; Wadman 2001; Whestphal 2002). Opponents of the patents argue that they could stifle the invention of alternative diagnostic techniques and limit patient access to the tests, especially in public 
healthcare systems, since there is no check on what Myriad can charge. They have also expressed concern about the company's policy that tests requiring full sequencing of the BRCA genes be sent to their laboratories for completion (Rimmer 2003). This raises the prospect of Myriad being able to construct a large proprietary database to reinforce its dominance in this and perhaps other areas of clinical research. Opposition to the Myriad patents has culminated in a legal challenge by the Institut Curie in France and other research agencies in Belgium and the Netherlands, supported by their respective national governments (Henley 2001; Rimmer 2003). Myriad has responded to these criticisms by arguing that patents allow them to protect their investment in this costly area, and to provide tests of the highest quality (Rimmer 2003). In Britain, Myriad originally signed a licensing agreement with a British company, Rosgen, to conduct BRCA tests for private healthcare patients, but this company has since gone into liquidation. Negotiations with the Department of Health about the provision of BRCA1 testing for National Health Service (NHS) patients are ongoing (Meek 2000a, 2000b). In the meantime, NHS laboratories continue to perform their own in-house tests without payment of royalties to Myriad (Nuffield Council on Bioethics 2002).

\section{Focus group methodology}

We convened a range of discussion groups as part of our research into expertise and citizenship in terms of the new genetics. These can be broadly termed focus groups because we, as the researchers, moderated each group and emphasized interaction between group members rather than between individual participants and ourselves. In this chapter, we present data from eleven groups: genetic counsellors; members of a support group for people affected by cancer; members of a government advisory commission on genetics; school pupils; members of an umbrella organization for people affected by genetic conditions; refugees; members of a Friends Meeting House; members of campaign groups concerned with genetics; university scientists; clinical geneticists/genetic nurses; and actuaries with an interest in genetics. With the exception of the members of the umbrella organization for people affected by genetic conditions, the people in these groups already knew each other. Some, such as the clinical geneticists, actuaries and policy advisers, worked together closely. Others met regularly in religious (Friends Meeting House group), educational (school group) or conference (counsellors) environments. Most of these groups involved around four people. Only two people turned up to the group for members of the umbrella organization for people affected by genetic conditions. We have still called this a focus group, however, because the same format was 